\title{
Humanismo y socialismo en la óptica del pensamiento marxista en América Latina
}

\author{
PABLO GUADARRAMA GONZÁLEZ
}

$\mathrm{E}$

N 1968 Alejandro Dubcek decía que "si el socialismo no adquiere un rostro humano desaparecerá como sistema" (1). Sólo hubo que esperar dos décadas de indiferencia ante este llamado por parte de los partidos comunistas en el poder en Europa Oriental para que su lamentable vaticinio se cumpliera.

En la autopsia actual aparecen múltiples causas de distinto orden, pero entre ellas despunta una tan fundamental como sencilla: los hombres encargados de desarollar el proyecto revolucionario y socialista en aquellos países no quisieron continuarlo porque no se sentían ya identificados con él. No veían reflejadas en sus realizaciones las aspiraciones humanistas que animaban originalmente al proyecto socialista.

Mientras tanto, en otros países, como China, Corea, Vietnam y Cuba, con independencia de sus notables particularidades, la historia se revela como testaruda, ya que en ellos el pueblo, en su gran mayoría, sigue confiando en el proyecto humanista que indisolublemente debe animar a toda forma de socialismo. Por eso lo siguen cultivando.

El marxismo es una de las corrientes de pensamiento que mejor heredó las tradiciones del humanismo de la antigüedad y la modernidad (2), pero, como planteaba el venezolano Ludovico Silva, Marx era un humanista "de sentido distinto" (3). Tanto él como Engels trataban de propugnar con el socialismo una utopía concreta cuyo ingrediente fundamental era un humanismo de nuevo tipo.

El humanismo con un sentido más práctico que aquel preconizado por los pensadores renacentistas o de la ilustración no fue un atributo exclusivo del ideario marxista. Hombres en distintas latitudes y ante circunstancias de distinto orden exigieron un humanismo auténtico, es decir, práctico. América Latina conserva en su historia hombres de la talla de Bolívar, Martí (4), Sandino, que hicieron del humanismo un estandarte permanente tanto de sus acciones más heroicas como de las más cotidianas. En el Che, Fidel y otros marxistas latinoamericanos, el humanismo cobró otras dimensiones teóricas y prácticas. Con el marxismo, el humanismo adquirió un perfil más definidamente clasista y proletario. Pero mucho más significativo fue que se desentrañaran científicamente los mecanismos subhumanizadores del capitalismo y se indicaran las posibles vías de su superación. 
El objetivo que se plantea el presente trabajo está dirigido a valorar algunas interpretaciones del pensamiento marxista latinoamericano, fundamentalmente en la esfera intelectual, sobre la articulación entre el ideario socialista y el humanismo que es consustancial a esa teoría. En análisis anteriores se ha intentado determinar cuáles han sido algunas de las exigencias que se le plantean al socialismo a partir de la experiencia del derrumbe del campo socialista (5). Ahora se trata de determinar las características y tendencias principales que se han dado en dicho pensamiento en relación con esta problemática del humanismo.

Se sabe de antemano, en acuerdo con otros investigadores del pensamiento filosófico marxista en América Latina - tal es el caso de Raúl Fornet-Betancourt (6) y en otras latitudes, como acertadamente plantea Pedro Ribas para el caso de la historia del marxismo en España (7), que la tarea se hace muy difícil si no se articula a la historia de los movimientos sociales y políticos, especialmente de la clase obrera, de la región que se estudie.

Siempre se exigiría realmente una investigación multidisciplinaria, pero también es posible, como ahora se pretende, tomar en cuenta los resultados de otros especialistas de las ciencias sociales e incursionar en algunas de las particularidades latinoamericanas de la imbricación histórica en el ámbito intelectual entre ideas socialistas, marxismo y humanismo. Por otra parte, es preciso tener en consi deración que el concepto de marxista no presupone necesariamente la militancia en partidos comunistas, socialistas etc. Aunque sí presupone una posición política de izquierda.

Además de la imprescindible coincidencia con las tesis fundamentales o núcleo duro de la concepción dialéctica y materialista de la historia, aquella condición debe estar avalada por la necesaria postura crítica frente al capitalismo, en todas sus formas, por preconizar ideas de orientación socialista, o al menos que subviertan el orden social existente y se planteen una más justa distribución de la riqueza social, así como un cambio radical en las relaciones del poder político.

Si bien la mayor parte de los intelectuales de ideas marxistas han militado alguna que otra vez en dichos partidos, esto no ha sido siempre sin dificultades, distanciamientos y hasta rupturas. La mayoría no se ha dejado cautivar por las posiciones del anticomunismo cuando se han dado estos conflictos. Precisamente por esa razón continúan siendo de izquierda, como también lo son otros que básicamente desde la vida académica se han destacado por sus posiciones marxistas y han expresado claramente su desaprobación tanto del socialismo soviético como de las posiciones de los partidos comunistas latinoamericanos.

El presente análisis no pretendió abordar este problema en el seno de partidos o movimientos sociales, para lo cual hubiese sido necesario un mayor trabajo de búsqueda documental de congresos, resoluciones, declaraciones, discursos políticos etc. Sólo se intentó - con la conciencia de la limitación del objeto abordalo a través de algunas manifestaciones de intelectuales de izquierda, en su mayoría reconocidos como marxistas, si bien quizás algún lector pueda por sus razones excluir a alguno de ellos, o autoexcluirse dado el caso. 
Fue en la tradición del pensamiento marxista donde el humanismo alcanzó una proyección de mayor trascendencia y arraigo por la propuesta desalienadora que propugnaba desde los trabajos tempranos de los fundadores de aquella teoría, que concibieron como socialismo científico, expresión convicta de su necesidad histórica. Pero la carga ideológica que acompañaba a este discurso lo confundía con otras doctrinas emancipatorias comunistas, socialistas, anarquistas etc. Muchos apreciaron, desde sus primeras manifestaciones y acciones inspiradas en su ideario, que se trataba de un proyecto revolucionario de relevancia muy superior a todos los que le habían antecedido y que su sentido humanista tenía dimensiones mayores a las acostumbradas. Aun cuando no dejase de destilar ciertos ingredientes no menos utópicos que los que criticaba en otras corrientes ideológicas de su época. El elemento utópico - ha reconocido uno de los más prestigiosos pensadores marxistas, Adolfo Sánchez Vázquez (8) - siempre estará presente en el socialismo, aun cuando se trata de una empresa racional que descubre lo posible en la utopía.

Otras tradiciones de pensamiento, tanto de las izquierdas reconocidas (socialistas, anarquistas, demócrata-revolucionarias, entre otras) así como concepciones religiosas y éticas de diverso matiz, también se han nutrido de aquel humanismo. Ellas han sabido a su vez cultivarlo y recoger alguna de sus fructíferas cosechas y, de tal modo, éste se ha traducido en distintos movimientos sociales, escuelas de pensamiento etc.

El humanismo, desde que maduró la modernidad, reclamaba revelarse a través de componentes más efectivos que las filantrópicas declaraciones de la ilustración. El marxismo le ofreció vías de concreción a través de ensayos prometedores de realización, por el nuevo paradigma de socialismo que éste preconizaba. Las propuestas humanistas del marxismo podrían entroncar armónicamente con las tradiciones de pensamiento de distintas regiones, culturas y países que evidenciasen a su vez un marcado carácter humanista.

En América Latina, donde la carga humanista y desalienadora había estado presente de un modo u outro a lo largo de la trayectoria de su pensamiento más significativo, no resulta estraño que la recepción del marxismo entroncase con esa herencia. De ahí que algunos pensadores, provenientes de corrientes distantes del proyecto socialista, llegasen a reconocer, desde fines del siglo pasado y en mayor medida a inicios del presente (9), el contenido humanista que subyacía en la obra de Marx y de muchos marxistas. No significaba que se identificaran, ni mucho menos, con todas las experiencias y los ensayos de proyección socialista que se emprendían en nombre del marxismo. Marxistas convictos y confesos, como Mariátegui en su defensa del marxismo, insistieron en reivindicar el carácter humanista y las potencialidades de perfeccionamiento ético y espiritual contenidos en el marxismo (10). Sin embargo, durante algún tiempo, el destacado pensador peruano fue visto con recelo por el marxismo oficial (léase el de los partidos comunistas), al no ser claramente apreciado su marxismo y sobre todo su materialismo desde la lejana latitud moscovita.

Algunos de los intelectuales marxistas latinoamericanos más destacados tenían clara conciencia de que su labor era continuadora de las mejores tradiciones del 
pensamiento latinoamericano. No en balde los marxistas cubanos Mella, Marinello, C.R. Rodríguez etc. plantearon no sólo la urgencia de reivindicar a Martí, sino, además, que era necesario volver a Marx para rescatar el valor de su propuesta humanista, como se percataban por entonces también otros marxistas latinoamericanos de aquellos años.

Entre quienes se percataron de su necesidad, se destacó Aníbal Ponce, quien en 1935 parecía vaticinar los nefastos augurios postmodernistas actuales contra el humanismo al plantear: "La historia contemporánea nos enseña que en manos de la burguesía el humanismo está en trance de morir. Y morirá sin duda, si el proletariado no le arrebata a tiempo, junto con la hegemonía económica, la dirección de una cultura que en el momento actual sólo ha sabido envilecer" (11). De esa misma tarea es de lo que hoy se trata cuando la imposición de medidas neoliberales aplasta toda supervivencia de humanismo.

En tiempos de auge del fascismo se hizo muy necesario exaltar el contenido humanista de las propuestas socialistas y en especial del marxismo. Lo trágico del asunto resultó cuando se fueron descubriendo los atentados más profundos a dicho contenido con las revelaciones del stalinismo y las experiencias totalitarias de algunos partidos comunistas en el poder, que aplastaban la individualidad y ponían serios obstáculos a las libertades ciudadanas.

En el período postbélico se fueron intensificando las investigaciones filosóficas sobre las obras de Marx, algunas de ellas recién editadas, y pudo apreciarse que afloraba el tema de la enajenación como una constante en sus preocupaciones desde sus años juveniles hasta El Capital. Es la misma época en que el existencialismo, el personalismo, la Escuela de Francfort etc. le dedican mayor atención al asunto, como una urgencia teórica de los nuevos tiempos. Sin embargo, el mundo del socialismo real quiso ofrecer la imagen de inmunidad ante esta problemática de la alienación, considerada erróneamente como exclusiva del capitalismo.

Por tal motivo las concepciones de Lukacs (1923) sobre la cosificación en Historia y conciencia de clase eran apreciadas como revisionismo idealista, ya que en lugar de reducir exclusivamente este fenómeno al capitalismo, el pensador húngaro incluso admitía que "el fenómeno de la cosificación también ha representado su papel en la sociedad griega evolucionada" (12), aun cuando reconocía la extraordinaria diferencia entre aquellas manifestaciones y la que alcanzaba en la sociedad burguesa. Pero una simple inferencia lógica podía llevar a pensar que entonces el fenómeno alienatorio no era exclusivo de la sociedad capitalista y, por tanto, también el socialismo estaba en peligro de contagio.

Henri Lefebve, quien contribuyó notablemente a la divulgación de las ideas del joven Marx y a la popularización del término marxiano de alienación (13) en su obra El materialismo dialéctico (1938), señalaba que el marxismo oficial rechazaba el concepto de enajenación y, junto con él, por supuesto, al propio Lefebvre.

No resultaba extraño que el pensamiento marxista latinoamericano, permeado hasta inicios de los 60 por un predominio de posiciones que seguían en lo funda- 
mental al pie de la letra las tesis de dia-mat, también se caracterizara por no incursionar decisivamente en esta temática. El grado de simplificación, de dogmatismo y extrapolación ideologizante que caracterizó por lo general al marxismo latinoamericano durante las décadas del 40 y el 50 fue expresión de su inautenticidad y de su limitado carácter creativo.

En cambio, la década del 60 tuvo para la evolución del pensamiento marxista en América Latina un especial significado. No sólo por un acontecimiento de tanta envergadura como la Revolución Cubana, sino por varios sucesos internacionales del pensamiento y la práctica política marxista (Gramsci, el Che, Mao, Althusser), que tendrían su repercusión particular en la recepción y desarollo del pensamiento marxista en esta región a partir de entonces. Para el mundo latinoamericano especialmente, el proyecto socialista de la Revolución Cubana significó la posibilidad de recuperar el espíritu humanista originario del marxismo. Y en tal sentido, esta nueva y diferente experiencia de construcción socialista reanimó a muchos hombres de izquierda afectados por aquella crisis de valores. Aunque también es cierto que la paulatina integración de Cuba al campo socialista condujo a nuevas frustraciones y distanciamientos por parte de algunos sectores de la izquierda latinoamericana.

Otros sectores con mayor razón se mantuvieron firmes y convictos de la autenticidad de la orientación consecuentemente socialista y por tanto necesariamente humanista del proyecto cubano, y hasta el presente le siguen apoyando, aun cuando discrepen de él en algunos aspectos.

En los años 60 el marxismo inunda toda la vida intelectual de las universidades latinoamericanas y no hay esfera de las ciencias sociales que no se hubiese visto influenciada por él. Es en medio del auge de la interpretación omnicomprensiva konstantinoviana del marxismo en que aparecen interesados en rescatar la autenticidad de los análisis de Marx sobre el fenómeno de la alienación y sus atentados contra la libertad humana, y la construcción del humanismo real que lo había animado.

En 1962, José Revueltas, después de reconocer que "el marxismo-leninismo había sido completamente desvirtuado en México y había que regresar a su fuente viva y regeneradora" (14), planteó que "una supresión no positiva de la propiedad privada no significaría la desenajenación real del hombre" (15). Afirmación ésta - como otros tantos cuestionamientos del polémico intelectual mexicano sobre el papel del partido, la lucha de clases, la dictadura del proletariado, el realismo socialista etc. - que lo llevó a frecuentes descalificaciones como marxista, pues al parecer no encontró el visto bueno del marxómetro oficial.

Por esa época Rodolfo Mondolfo fundamentaba también, en Argentina, el humanismo de Marx como un humanismo realista (16) y, acentuando su carácter de filosofía de la praxis, con los elementos de dinamismo y vitalidad que deben distinguirlo, señala que "no se trata de un materialismo, sino de un verdadero humanismo, que pone en el centro de toda consideración y discusión el concepto de hombre. Un humanismo realista (reale Humanismus), como lo llamaron sus 
propios creadores, y que aspira a considerar al hombre en su realidad efectiva y concreta" (17).

No debe ignorarse que el criterio prevaleciente sobre el materialismo, incluso hoy en día, en la mayor parte del mundo cultural latinoamericano, no se distingue mucho del que existía hace un siglo. Se le caracteriza generalmente por la vulgaridad, el apego a los bienes terrenales y subestimación o desprecio por el enriquecimiento de la espiritualidad. Tantos siglos de combate entre la Iglesia y el materialismo no desaparecen fácilmente en la conciencia social latinoamericana.

En varios países afloraron por esos años las discusiones encaminadas a revitalizar el marxismo profundizando en su cientificidad, la teoría de la enajenación, la libertad y el humanismo, la filosofía de la praxis, el papel real de las ideologías etc. Entre ellos se destacaron México, Perú, Venezuela, Colombia, Argentina y Cuba, aunque también estos temas ocuparon la atención de algunos destacados intelectuales de otros países del área.

Los intelectuales en Cuba, durante los años 60, manifestaron inicialmente interés teórico por el asunto. Pero el despliegue de tal preocupación tomó más fuerza en aquellos otros países que en la isla. Cierto marxismo tarado por los manuales soviéticos y otros textos que propugnaban uma concepción simplificadora del asunto también comenzaban a ganar posiciones desde mediados de esa década y llegarían a predomiar, en los 70 y hasta mediados de los 80 , con la mayor articulación de Cuba a la comunidad de países socialistas europeos.

En anteriores estudios nos hemos detenido en la evolución del pensamiento marxista en Cuba, fundamentalmente hasta el inicio del triunfo de la revolución (18). En cuanto a la evolución del pensamiento marxista en Cuba de los últimos años, no es objeto específico del presente análisis y se trata de una tarea que ya se ha emprendido.

Las preliminares consideraciones al respecto conducen a pensar que no siempre el pensamiento marxista académico en el orden teórico estuvo a la altura de las demandas de la transformación y perfeccionamiento de la praxis política. También se aprecia que su relativo distanciamiento recíproco de la producción teórica marxista del Occidente, y en particular de América Latina, constituyó un obstáculo comunicativo que finalmente ha sido paulatinamente superado el los últimos años.

Una situación muy distinta se presentó en el resto del continente en relación a estas inquietudes antropológicas del pensamiento filosófico. Así, por ejemplo, en Venezuela "hacia los inicios de los años 60 el ambiente universitario estaba impregnado de marxismo o de lo que pasaba por tal" (19), considera Eduardo Vásquez. "Fue en ese ambiente de dogmatismo y de estupidización masiva y galopante donde aparecieron los términos alienación y cosificación" (20).

¿Cuáles serían las razones para que proliferara en aquel ambiente esta temática descuidada anteriormente en la literatura marxista que circulaba en Latinoamerica? Todo parece indicar que muchos filósofos latinoamericanos de pronto encontraron 
en la obra de Marx suficiente argumento de raigambre eminentemente filosófica para combatir a aquellos que desvirtuaban al marxismo como filosofía y lo presentaban como una simple ideología, una teoría sociopolítica más, o a lo sumo una aceptable doctrina económica sobre el capitalismo decimonónico.

Tales aristas filosóficas permitían discurrir con envidiable rigor filosófico en ambientes académicos que usualmente, por esos años, en América Latina, eran monopolizados por la fenomenología, el existencialismo básicamente heideggeriano, la axiología objetivista y comenzaban a ser conquistados con fuerza por la filosofía analítica.

Todo ello a partir de esta revelación que había tenido sus orígenes en la pretensión sartreana de completar el humanismo de Marx y que prosiguió en los debates en la Francia de los 70, presupuestamente en el seno del marxismo, entre el antihumanismo teórico althuseriano, el humanismo espiritualizado de Garaudy, la consideración crítica de Lucien Seve del marxismo como "adversario teórico irreductible del humanismo especulativo" (21), y las críticas de Goldman a la URSS y demás países socialistas por desatender los valores conquistados por el humanismo occidental (22) etc.

Todas estas polémicas se trasladaban vertiginosamente al ámbito intelectual latinoamericano de la época y de una forma u outra se participaba en ellas no como simple eco, sino asumiendo posturas de creación heroica y aportando valiosos elementos nuevos que se hace necesario investigar con mayor profundidad a fin de revelar la autenticidad del pensamiento marxista latinoamericano de las últimas décadas de este siglo. Indudablemente tales debates intelectuales eran en el mejor de los casos ignorados, pero por lo general resultaban anatemizados por las directivas de muchos de los partidos comunistas latinoamericanos, que se dejaban aconsejar por sus especialistas, por lo general formados en las escuelas del PCUS y de otros países del campo socialista, donde habían aprendido a no permitir la menor desviación de los revisionistas y otros engendros.

Hoy es lamentable el balance de aquella política sostenida durante décadas contra honestos intelectuales de profunda filiación marxista, que disentían tanto de lo que era encumbrado como expresión práctica superior del humanismo socialista como de muchas de las formulaciones teóricas que apuntalaban aquel sistema. Sin embargo, la mayor parte de éstos no renunciaron a sus empeños de investigación y comunicación. Se mantuvieron consecuentes con sus verdades y las defendieron con un rigor teórico que hoy enorgullece la producción filosófica marxista en esta región.

Tampoco se puede pensar simplemente que todos aquellos que mantuvieron una militancia política ininterrumpida descuidaron la atención unilateralmente sobre los debates referidos a la reivindicación del humanismo real que debía sustituir al socialismo real. Algunos llegaban a coincidir con los argumentos esgrimidos por los disidentes, pero consideraban en ocasiones que resultaba más prudente aplazar la discusión por cuestiones estratégicas. No prevaleció el criterio de que a la larga resultaría más nefasto que beneficioso el aplazamiento que el abordaje desprejuiciado de aquellos sillares marxistas de la construcción que demandaban ser remozados. 
Una revalorización de esta índole tendrá que tener en cuidadosa consideración la labor de Ludovico Silva por desentrañar los laberintos ideológicos de la enajenación y la renovación del marxismo que, como filosofía, no se ha caracterizado por ser de transformación (23) - lo que quiere decir también ser auténtica, especialmente en las circunstancias sociales latinoamericanas - sino de apologética conservación como el resto de las filosofías contemporáneas.

Volver a Marx se convirtió, como lo sigue siendo hoy, más que una consigna, una urgencia teórica, pues por un lado se habían mantenido sin publicar algunas de sus obras cruciales y otros documentos reveladores de la riqueza de su pensamiento científico y humanista, y por otro se habían forzado muchas interpretaciones para justificar las prácticas políticas más controvertidas y cuestionables desde una perspectiva genuinamente de humanismo socialista.

A inicios de los 80, Oberdán Caletti, dando muestras de las justificadas dudas que tenían muchos marxistas latinoamericanos sobre la concreción del humanismo en los entonces países socialistas, planteaba en Argentina que: "En el convulsionado mundo de hoy, que plantea imperiosas interrogantes de orden social, político y económico, se advierte con mayor extensión la exigencia de un retorno a Marx. Pero no al Marx de los regímenes que mediatizan al hombre y condicionan su libertad, sino al Marx del humanismo socialista, al que proclama al hombre y sus libertades como fines en sí mismos" (24). No era necesario esperar a que se produjese la perestroika para que esta intelectualidad marxista heterodoxa criticara las limitaciones que se le habían impuesto al original ideario humanista del socialismo tras las justificaciones por salvaguardar las conquistas del socialismo a todo precio.

Tampoco para este tipo de intelectuales críticos era necesario que tomara auge la glasnost para que proclamasen a los cuatro vientos que el marxismo estaba en crisis, al concebir dicho proceso no de forma peyorativa, como el triunfalismo soviético sobre el capitalismo usualmente propugnaba, sino de una forma más adecuada, entendiéndola como momento alternativo necesario de posibilidad de superación y fortalecimiento - como la concebía en los 70 José Aricó (25) - aunque también admitiendo la posibilidad de su deterioro si no se asumía la postura revitalizadora imprescindible.

La intelectualidad latinoamericana de izquierda no ponía en duda el contenido eminentemente humanista del pensamiento de Marx, pero sí que la práctica del socialismo realmente existente fuese su adecuada expresión. Mientras tanto, era el conformismo o la apologética lo que caracterizaba al marxismo oficial de los países socialistas y sus intransigentes defensores en otras latitudes, como la latinoamericana.

Una posición no menos marxista, incluso mucho más auténtica - por hacer en general un uso adecuado de la crítica - se evidenciaba en aquellos cultivadores del llamado marxismo occidental, tendencia que desde sus primeras manifestaciones se caracterizó por rescatar el humanismo real y concreto de Marx, aunque por lo general sus seguidores injustamente desconocían similar valor en Engels.

Algo que preocupó a la intelectualidad de izquierda latinoamericana fueron 
las acusaciones al marxismo de atentados contra la individualidad, así como de disolver en un colectivismo aplastante las diferencias reales existentes entre los hombres. En oposición al egoísmo y al individualismo burgués, algunos intelectuales de izquierda o progresistas, aunque no siempre marxistas, como el transterrado Juan David García Bacca, que invocaba al humanismo positivo de Marx (26), los colombianos Antonio García, Gerardo Molina y Stanislao Zuleta, reivindicaron la preocupación existente en la obra de Marx por la genuina realización de la individualidad. Se enfrentaron al igualitarismo que algunos ensayos del socialismo real habían implantado, en evidente distanciamiento del espíritu originario del ideario socialista que pretendía asegurar a cada individuo iguales posibilidades pero sin la intención de meterlos en un lecho de Procusto.

Antonio García - de quien Marcuse destacó los valiosos análisis marxistas -, en su prolífica obra, que aún espera por investigaciones más amplias, planteaba la urgencia "de dar una conformación racional a la sociedad, lo que equivale a decir que el individualismo humanista debe transformarse en socialismo humanista" (27). Ese tipo de socialismo, él no lo veía realizado en la mayoría de los entonces países socialistas y por tal razón su búsqueda de nuevos paradigmas de socialismo hizo que fuese caracterizado como heterodoxo. El hecho de que García le dedicara especial atención a la cuestión indígena también lo separaba de las líneas principales del marxismo tradicional y le otorgaba un carácter mucho más concreto a su humanismo.

Situación algo similar fue la de Gerardo Molina, quien, al defender las ideas de un socialismo democrático más humano, se opuso a las falsas ideas igualitaristas que se esgrimían en nombre del socialismo y a las ilusorias ideas de la realización del país de jauja (28). Otras ideas relevantes de Molina que merecerían análisis independiente fueron sus consideraciones de que el socialismo en América Latina sólo podría prosperar ligado a soluciones hemisféricas y a la vez no dependiendo exclusivamente de la clase obrera.

Por su parte, Stanislao Zuleta insistió en lo que llamó el individualismo radical (29) de Marx, debido al carácter concreto que éste planteaba en la solución de los problemas del hombre frente al individualismo abstracto del idealismo filosófico. Para lograrlo, el marxismo debía, y estaba en condiciones de hacerlo, construir una nueva antropología, mucho más realista (30), esto es, menos ilusoria, como acostumbraban las idílicas premoniciones del marxismo oficial respecto al futuro ideal comunista. Algo que comenzó a tomar fuerza en la intelectualidad marxista colombiana fue el hecho de apreciar la obra de Marx y en especial sus métodos de análisis para interpretar la realidad socioeconómica, política y cultural del país (31).

En tal sentido, la labor del sociólogo Orlando Fals Borda ha trascendido su país, ante todo porque se planteó el estudio de su realidad, tomando como premisa que "el marxismo es una ciencia corregible y ampliable como toda ciencia útil; no está petrificado como lo hubieran querido los stalinistas" (32).

Tal distanciamiento de la visión omnicomprensiva del marxismo propugnada por el dia-mat hizo posible que se plantearan no sólo la tarea de aportar tesis de valor científico a la concepción materialista de la historia en su sentido más general, 
y en particular a la compleja estructura socioclasista de las sociedades latinoamericanas, sino algo que resulta más importante: la búsqueda de propuestas de orientación socialista para este contexto específico (33), que se distanciaran del modelo del socialismo real.

La preocupación de Marx y Engels por la individualidad, expresada desde sus trabajos tempranos, había llamado la atención a numerosos pensadores latinoamericanos, incluso no marxistas, como el uruguayo Carlos Vaz Ferreira (34).

Cuando se trataba de intelectuales declarados de izquierda o militantes, estas ideas, paradójicamente de raigambre marxista, podían resultar disonantes con el discurso tradicional de los partidos comunistas de la época, que mantenían como principio esencial la subordinación de los intereses individuales a los del colectivo, la clase, el partido o la sociedad. Tal es el caso del argentino Alfredo L. Palacios, quien tras su visita a Cuba, al exponer lo que consideró una revolución auténtica, sostuvo ante el senado de su país: "Porque soy socialista me siento profundamente individualista. El socialismo es la doctrina que permite el desenvolvimiento de todas las facultades del espíritu, es decir lucha por la libertad porque el fin del hombre es la libertad" (35). De lo que se puede inferir que en la intelectualidad de izquierda latinoamericana predominó generalmente una visión muy enriquecida de la espiritualidad y en defensa de las conquistas modernas de la individualidad que presupone un socialismo más apropiado.

Factores de carácter político, sobre todo el temor de ser manipulados por los aparatos ideológicos del poder dominante, incidieron en que otros tantos intelectuales, más comprometidos con uma militancia en partidos de la izquierda, no se pronunciaran abiertamente contra los defectos de aquellos ensayos socialistas de la época.

Pero resulta evidente que la concepción prevaleciente entre estos intelectuales de lo que debía ser el socialismo y las conquistas del humanismo, que era aún necesario alcanzar, era muy distante de la autocomplacencia reinante en el entonces campo socialista. Desde muy temprano, en estas tierras, no sólo enemigos declarados del socialismo, sino también muchos simpatizantes criticaron el distanciamiento y finalmente la ruptura del stalinismo primero y después de los países que se formaron bajo su influencia en relación con el proyecto humanista del socialismo. Entre ellos se destaca el antropólogo brasileño Darcy Ribeiro, quien ha sostenido que "el marxismo se redujo a ser una doctrina justificatoria del ejercicio del poder, susceptible de distanciarse de sus fundamentos filosóficos y de las lealtades humanistas que profesaba" (36) (el subrayado es nuestro).

Otros que confundieron el ideal marxista con la práctica del socialismo real se deslizaron por el sendero del escepticismo social y algunos terminaron en el anticomunismo. En tanto los que supieron diferenciarlo adoptaron por lo regular una actitud crítico-constructiva sugerente de alternativas, pero casi siempre dentro del ideario socialista. Una postura más objetiva es aquella que reconoce los indiscutibles logros alcanzados por la experiencia socialista (37), que en definitiva fueron conquistas parciales del humanismo y del progreso social, como ha reconocido en Ecuador Enrique Ayala Mora (38), entre otros marxistas latinoamericanos. 
Por lo general se lograron superiores niveles de educación, salud pública y seguridad social que los que poseían la mayor parte de los pueblos de Europa Oriental y del Asia que emprendieron la experiencia socialista. Muchos analistas coinciden en el valor de estos logros, aunque a la vez consideran que las causas del derrumbe de ese ensayo socialista fueron básicamente endógenas (39).

Aquellos logros constituyeron conquistas innegables con independencia de los errores y abusos cometidos. Pero a la larga estos últimos incidieron en que las propias masas populares favorecidas por las conquistas sociales prefirieran finalmente renunciar a ellas en espera de encontrar con cambios radicales una situación en todos los sentidos superior.

Hoy en día la experiencia del capitalismo real no resulta tan satisfactoria para la mayoría de la población, como esperaba esa gente, pues como señala en Venezuela Hugo Calello, "el neoliberalismo pragmático, economicista, es una propuesta que oculta el abandono de los supuestos éticos políticos del humanismo, supuesto básico de la democracia" (40). Este indiscutible hecho pone de manifiesto el carácter contradictorio, en última instancia, entre el capitalismo y la genuina democracia, aun cuando ella haya alcanzado conquistas indudables durante el despliegue de esta sociedad.

El capitalismo no puede estimular por su propia naturaleza el humanismo genuino y concreto porque éste atenta contra la supervivencia de los capitalistas como clase privilegiada. El socialismo, por su parte, con independencia de las deformaciones que se produjeron en sus primeras experiencias, debe asentarse sobre pilares eminentemente humanistas desde todo punto de vista. De lo contrario hay razones suficientes para cuestionarse el carácter propiamente socialista de dichos ensayos, como han hecho, entre otros, Aníbal Quijano en Perú (41), Longino Becerra en Honduras (42), Eduardo Galeano en Uruguay y Gabriel Várgaz Lozano y Adolfo Sánchez Vázquez en México (43).

Muchos de estos autores se suman a los que, en varios eventos acerca de la caída del socialismo efectuados en varios países latinoamericanos en los últimos años, coinciden (44) en considerar que la imposibilidad de realización del socialismo en estos países estuvo dada por las limitaciones que tuvo para su realización la democracia (45).

El criterio de que es imprescindible que las personas tengan acceso a suficientes fuentes informativas (46) así como posibilidades comunicativas es algo común en las reclamaciones de la intelectualidad marxista latinoamericana como premisa básica para la construcción humanista del socialismo. A partir de la justificada crítica a las insuficiencias y formalidades de la democracia burguesa, la visión dialéctica del asunto no funcionó como para que permitiera un adecuado uso de las conquistas de la democracia en su sentido más amplio, el cual no se reduce a la labor de la burguesía en su tarea por conquistar el poder; pero dicha visión tampoco puede ser ignorada o, lo que es peor, no aprovecharse en favor del socialismo.

Resulta indiscutible lo planteado por Enrique Semo acerca de que "el socialismo sólo puede contribuir al humanismo del siglo XXI partiendo del pleno 
reconocimiento del colapso del socialismo realmente existente" (47), pues resulta inaceptable ignorar este hecho en cualquier tipo de reconsideración de las fórmulas socialistas. Y con ese objetivo deben reanalizarse aquellas causas que alienaron al hombre en dicha sociedad, les hicieron perder su iniciativa creadora al trabajador (48) y lo distanciaron de algún modo del proyecto humanista originario contenido en el ideario marxista.

La publicación de algunas de las obras juveniles de Marx, la polémica que inició el existencialismo francés y puso en el microscopio el humanismo en el marxismo, así como las repercusiones en esta región del althusserianismo contribuyeron a que la intelectualidad marxista latinoamericana reconociera otras aristas del significativo lugar que tenía la reflexión antropológica y en especial la proyección humanista del marxismo, ya que el marxismo soviético no lo abordaba satisfactoriamente.

Si bien es cierto que en América Latina la política de los partidos comunistas tradicionales consistió por lo general en salvaguardar el proyecto soviético y el socialismo real a partir de la imagen deformada que poseían de aquellas sociedades, también esta región ha sido espacio propicio para que desde las propias filas del marxismo fructificase, desde temprano, la crítica a las desviaciones prácticas del proyecto humanista originario de esta teoría. No fue casualidad que Trotsky y sus ideas tuviesen acogida aquí, que emergieran personalidades como Mariátegui o el Che, considerados como heterodoxos, y que Gramsci, Lukacs y en general el llamado marxismo occidental hayan tenido recepción tan especial en Latinoamérica. La herencia humanista de la tradición del pensamiento latinoamericano, expresión también de su autenticidad, confluía mucho más con los rasgos y la propensión de este tipo de marxismo que con las incontrovertibles tesis del dia-mat.

Esto explica, en parte, también el porqué de la articulación de muchas de las ideas de Marx y algunos de sus continuadores occidentales con tres de las corrientes más originales que ha aportado el pensamiento latinoamericano en los últimos tiempos: la teoría de la dependencia, la teología de la liberación y la filosofía de la liberación.

Enrique Dussel ha reconocido adecuadamente que "los primeros pasos de la filosofía de la liberación a fines de la década del 60 se dieron en contra de una tradición marxista (un tanto dogmática, economicista o althusseriana). Fue un error. Pero el error no podía superarse simplemente adoptando el marxismo vigente. Era necesario repensar, releer el marxismo desde su origen y dentro de las hipótesis de una filosofía de la liberación. Por ello, como exigencia metódica, desde la realidad latinoamericana, desde los oprimidos (como clase, como marginales, como etnias, como 'pueblo histórico' o 'bloque social' de los dominados) se debía asumir a Marx mismo por un contacto directo con sus descubrimientos teóricos fundamentales" (49).

Es evidente que el marxismo entonces vigente era el marxismo-leninismo y, más que ello, la praxis político-social del socialismo real que apuntalaba no satisfacía plenamente las exigencias humanistas (50) de esta corriente filosófica surgida en América Latina. 
El marxismo, como apunta Horacio Cerutti, nutrió también a la teología de la liberación y a la teoría de la dependencia por su "carácter instrumental indudable y una riqueza eurística escindible de su sustento filosófico" (51). No sólo la proyección humanista y emancipatoria originaria en el marxismo, sino la cientificidad en que se fundamenta, hicieron que esta intelecutalidad también de izquierda, aunque no toda propiamente marxista, acogiera como suyas muchas de las tesis del marxismo menos contaminado de dia-mat y que mejor sirviese al estudio de la problemática de estos países periféricos. En tal sentido muchas veces la obra de Lenin fue justipreciada por estas corrientes del pensamiento latinoamericano, entre otros elementos, por sus reales aportes al análisis de las nuevas relaciones que se establecen con la época imperialista del capitalismo.

Algo que se aprecia en la trayectoria del marxismo en América Latina, con honrosas excepciones como la de Mariátegui (52), Antonio García, Vicente Lombardo Toledano, José Antonio Arze y Arze, entre otros, fue la no debida atención a la cuestión social del indio. Tal vez este hecho tenga que ver con lo apuntado por Héctor Díaz Polanco de que “...la problemática de las etnias y las nacionalidades oprimidas quedó siempre en segundo plano teórico en las preocupaciones de Marx y Engels, en la medida que se suponía que la cuestión étnico-nacional quedaría resuelta más o menos rápidamente en el marco de la nueva sociedad socialista” (53).

Aun cuando Lenin mostró preocupación por el asunto, dadas las características del territorio donde emergía el poder soviético, el acómodo de la mayor parte de los partidos comunistas a las tesis supuestamente elaboradas por Stalin sobre la cuestión nacional motivaron cierto descuido en general, y en especial sobre los problemas étnicos, en el ambiente académico y político latinoamericano.

A juicio del marxista mexicano Alberto Saladino García, el marxismo ortodoxo y reformista latinoamericano, impregnado por la tradición liberal para explicar la historia, no supo "sobreponerse a la visión negativa que tal corriente infundió acerca de las posibilidades propias del indio para erigirse en hacedor de su propia historia" (54).

Hay un hecho que, por lo tanto, ha sido muestra de inautenticidad: la inadecuada consideración en todas sus dimensiones de la cuestión indígena. No ha habido una consecuente continuidad del tratamiento que le ortogó el Amauta al problema y sólo en los últimos años, a raíz de algunos movimientos guerrilleros y otros movimientos sociales indígenas, ha habido un pronunciamiento más específico por parte de partidos e intelectuales marxistas. Aun cuando al conmemorarse los 500 años del inicio de la conquista y colonización de América por los europeos hubo un auge de arraigadas posiciones indigenistas, en la actualidad sus propuestas reivindicativas parecen alcanzar mejor articulación y objetividad. Se debilitan las ideas que pretendían oscurecer la lucha de clases con las luchas de las etnias. En la actualidad muchos revolucionarios latinoamericanos que luchan por las reivindicaciones indígenas, sobre todo en Nicaragua y Guatemala, han aclarado considerablemente la dialéctica real de la doble lucha (55), por lo que podemos considerar que han adoptado una posición mucho más auténtica. 
No se puede negar que en los últimos años la fuerza de los hechos dio lugar a que los partidos comunistas y otros partidos de izquierda, en aquellos países latinoamericanos donde la población originaria es importante, otorgasen cada vez mayor atención a la cuestión. Sin embargo, aun así muchos investigadores coinciden en que en general el pensamiento marxista latinoamericano desatendió algunas cuestiones vitales de carácter nacional.

El mimetismo ante esquemas socioeconómicos, políticos e ideológicos importados en ocasiones distanciaron a los marxistas latinoamericanos de ofrecer propuestas de análisis y soluciones adecuadas a los problemas específicos del contexto latinoamericano. No siempre se tuvo en cuenta aquella indicación de Ricardo Avilés: "Hay que estudiar nuestra historia y nuestra realidad como marxistas y el marxismo como nicaragüenses" (56).

La importación de cierto obrerismo extrapolado a circunstancias tan heterogéneas en cuanto al desarrollo capitalista, y otras posturas xenófilas que en distinto momento se produjeron en las concepciones del marxismo que se cultivaba en la otrora URSS o en otros países socialistas, atentaban contra la autenticidad del pensamiento marxista en América Latina. Las revelaciones de los atentados contra el humanismo llevado a cabo en nombre del marxismo-leninismo durante la época de Stalin, y las secuelas de algunos de sus procedimientos aun en años posteriores, pusieron en crisis la confianza de muchos hombres que hasta ese momento veían en el socialismo el non plus ultra del humanismo.

Muchos analistas coinciden en que entre las causas del deterioro de dicho ensayo figuran el auge que tomó el consumismo en aquellos países, que presumían de formar una nueva mentalidad humana ante la irracional carrera de producción de bienes materiales de secundaria necesidad generados por los mercados capitalistas.

Las causas del posible derrumbe del modelo soviético de socialismo fueron atisbadas no sólo por aquellos sovietólogos cuyo sueldo dependía de efectuar buenos pronósticos sobre los países entonces socialistas. También marxistas de distantes partes, entre ellos de América Latina, se percataron, entre otras cosas, de que mientras no se reivindicara de forma práctica y hasta sus últimas consecuencias el humanismo consustancial al socialismo marxista, cualquier proyecto que se emprendiera en su nombre ignorando estos principios estaría condenado al fracaso.

Desde el inicio de la perestroika algunos analistas, como Tomas Moulian, indicaban que muchas de las certezas preconizadas por el marxismo habían entrado en crisis, como la centralidad de la clase obrera y su hegemonía en todo momento, la idea de que la revolución vendría de un momento a otro; especialmente se debilitó la creencia de que el marxismo era la ciencia infalible de la historia y de la revolución, pero se confiaba en que "la derrota y la crisis suscitan la renovación, puesto que obligan a revisar las premisas teóricas y las prácticas utilizadas" (57).

Es todavía temprano para establecer un balance teórico de las repercusiones del impacto de la crisis del socialismo sobre la teoría, pero en definitiva se impone hacerlo. Es apreciable que si se dejan a un lado los slogans propagandísticos sobre la muerte definitiva del marxismo, ya se aprecia, tanto en el ámbito intelectual 
mundial como en el latinoamericano en especial, una prolífica labor de reconsideración crítica sobre el valor epistémico de la teoría marxista, con saldos muy favorables.

Como acertadamente planteara Rodolfo Cerdas, "la contribución que el marxismo ha hecho al desarrollo de las ciencias sociales en general, y a la histórica en particular, no puede anularse por la invalidación de algunos supuestos teóricofilosóficos, ni por la disolución final de muchas de sus realizaciones concretas en el campo económico, político y estatal” (58).

Uno de los síntomas más nefastos en cuanto al distanciamiento que paulatinamente fue tomando el socialismo real del humanismo marxista originario fue la reproducción, incluso la renovación, de formas de enajenación que se acrecentaron en aquellas sociedades, pues "no todas las formas de enajenación que se configuraron históricamente en los países socialistas tuvieron su base en la economía, también la hubo en las relaciones sociopolíticas" (59).

Una de las propuestas más audaces del humanismo marxista presupone la difícil tarea de generar una sociedad en la cual queden superados los mecanismos de enajenación que han engendrado hasta el presente las sociedades de clase y, en especial, el capitalismo. Por tal motivo cualquier manifestación de reproducción de este rasgo antagónico al humanismo debe significar a la vez un distanciamiento de la propuesta del socialismo marxista y, lamentablemente, todos los ensayos socialistas que se han emprendido hasta el momento no han podido superar este escollo, por cuanto parece que no podrá lograrse de manera aislada.

La atención a los problemas de la conciencia cotidiana, del enriquecimiento del sentido de la vida, de la dimensión íntima del hombre ante innumerables problemas existenciales, desde las enfermedades hasta la muerte, que durante algún tiempo se consideró no constituía una preocupación de la filosofía marxista sino de la llamada filosofía burguesa (60), ha pasado a formar parte sustancial de las preocupaciones del pensamiento filosófico de orientación marxista actual.

La crisis del socialismo ha obligado a la intelectualidad y a la dirigencia de izquierda en América Latina a aprender tanto de errores ajenos como de los propios en la búsqueda común del camino hacia el humanismo real añorado por Marx y Engels. Pero no para quedarse en la satisfacción de las expectativas de un pensador que, independientemente de su genialidad y su visión de futuro, tenía sus pies en el siglo XIX y por tanto no podía prever tan profundas transformaciones en todo el habitat humano de los tiempos presentes.

Se hace necesario destacar que las exigencias reivindicativas del humanismo no son exclusivas de los marxistas, sino que su radio de acción se expande algo más allá, pues se han constituido en demandas de toda la izquierda latinoamericana. Pero, indiscutiblemente, el carácter protagónico del humanismo marxista se revela fuertemente en todas estas propuestas que en análisis anterior hemos sintetizado del modo siguiente:

“¿Qué aspectos del humanismo marxista han sido más reivindicados 
últimamente por la intelectualidad de izquierda en América Latina? Entre los elementos que se considera deben ser reivindicados para rescatar el humanismo originario del marxismo, y por tanto ser consecuentes con la autenticidad del mismo, se aprecian los siguientes:

- La opción por el socialismo debe ser el resultado de una elección genuinamente popular independientemente de las vías por medio de las cuales ésta se plantee y se logre, pero jamás el resultado de una imposición de cualquier índole.

- En correspondencia con ese postulado la dimensión de lo social debe plasmarse lógicamente a través de la decisión individual, de manera que no se obligue a persona alguna a vivir en el socialismo en contra de su voluntad.

- El socialismo debe ser construido por productores libremente asociados y que se sientan dueños reales del proceso productivo en el sentido de poder tomar decisiones trascendentales que impulsen este proceso, siempre y cuando tales transformaciones se efectúen en beneficio de toda la sociedad y en primer lugar de los propios productores.

- El poder del Estado socialista debe orientarse fundamentalmente a salvaguardar y perfeccionar las conquistas sociales y políticas de la población, para lo cual debe ejecutar como todo Estado su función represora, siempre y cuando ésta se desenvuelva acorde con los derechos civiles internacionalmente reconocidos.

- El papel de partidos, sindicatos y organizaciones civiles debe circunscribirse específicamente a sus funciones y constituir instrumentos efectivos de representatividad y poder de sus asociados, de manera tal que el individuo los perciba como otras vías democráticas de acceso al poder, de reconocimiento y realización individual.

- Cada persona debe tener las condiciones reales de acceso a la educación, la salud, el deporte, el arte que posibiliten el despliegue de las aptitudes indivi-duales y le capaciten para el mejor despliegue de sus actividades productivas, de consumo, recreativas e intercambio en general, en correspondencia con su participación individual en el proceso productivo y social.

- Al concebirse el socialismo como una sociedad superior a la capitalista, se presupone que aquél debe superar las conquistas de la sociedad burguesa en lo que a libertades ciudadanas se refiere, entre las que se destacan la de elegir y ser elegido, de reunión, comunicación, movimiento etc. El hecho de que la experiencia de la construcción del socialismo - en la mayoría de las ocasiones con la justificación temporal necesaria, dado el auge de la reacción interna y externa - haya exigido restringir muchas de estas prerrogativas no significa que éstas hayan desaparecido del horizonte de expectativas de la izquierda latinoamericana que lucha por el socialismo, máxime en la época actual posterior al derrumbe de uno de sus intentos. 
Estas entre otras son algunas de las exigencias plasmadas en múltiples análisis desde la perspectiva de la izquierda latinoamericana y que no son muy distantes de las de otras latitudes" (61).

Según el mexicano Jorge Castañeda, "hoy pertenecen a la izquierda partidos, grupos, movimientos o dirigentes políticos que desde la Revolución Cubana han colocado el acento en el cambio por encima de la continuidad; en la democracia y los derechos humanos sobre la seguridad nacional; y en la identidad nacional y la soberanía sobre la integración económica (libre mercado, inversión extranjera etc.). En materia económica y social, la izquierda suele insistir en la justicia social sobre el desempeño económico (en los subsidios sobre el rigor fiscal, en el empleo sobre la eficacia, en el control nacional de los recursos naturales y sectores estratégicos de la economía sobre las políticas económicas de libre mercado y de libre empresa), en la distribución del ingreso sobre el buen funcionamiento de los mercados, en reducir las desigualdades más que en la competitividad, en el gasto social sobre el control de la inflación, en la necesidad del gasto sobre el imperativo del saneamiento de las finanzas del gobierno" (62).

Es indudable que todas estas formulaciones y caracterizaciones de la izquierda latinoamericana descansan en el más asentado principio humanista que ha prevalecido en la tradición progresista del pensamiento latinoamericano y universal. En la misma el ideario marxista y socialista alcanzó una articulación visceral en su formulación teórica y en sus aspiraciones, aun cuando sus indiscutibles realizaciones prácticas en los países que han intentado construir el socialismo se hayan visto afectadas por prácticas que han puesto en duda el humanismo que necesariamente conlleva el socialismo.

La pérdida de referentes en relación con un modelo de socialismo a partir de la actual crisis de paradigmas que produjo el derrumbe del socialismo real no significa que las fuerzas de la izquierda hayan renunciado de manera íntegra y total a la búsqueda de alternativas socialistas a las actuales circunstancias de avasallador triunfalismo neoliberal, con el agravamiento de la explosividad social que trae aparejado, especialmente en países periféricos, como los de América Latina. Sucesos como el caracazo en Venezuela, los movimientos de Santiago del Estero en Argentina y de Chiapas en México son suficientes para evidenciar que los conflictos sociales se han agravado y las soluciones no se atisban a corto plazo.

Por tal motivo acertadamente el historiador brasileño Jacob Gorender plantea: "Pienso que el socialismo real, resultado de una profunda crisis del capitalismo, es naturalmente tentativa de una alternativa social que fracasó indiscutiblemente, pero eso, a mi modo de ver, no es el fracaso de la idea del socialismo. El propio capitalismo hará que esa idea de nuevo gane fuerzas. A mi ver no hay outra doctrina que sirva de base, de punto de partida para una teoría socialista; no hay outra doctrina mas coherente que el marxismo, pero un marxismo que indispensablemente tiene que renovarse" (63).

La intelectualidad de izquierda extrae experiencias de la historia mundial y de estos últimos acontecimientos de la región y por lo regular llega a la conclusión 
de que la historia mantiene su sentido de progreso, a pesar de los altibajos que necesariamente siempre acontecen.

El socialismo - aun cuando sea a largo plazo - sigue estimulando la acción de muchos sectores de la izquierda latinoamericana, y en tal sentido éstos son consecuentes con los grados de autenticidad que siempre la han caracterizado como promotora de mayores niveles de humanización para el hombre latinoamericano.

A juicio del ecuatoriano Arturo Campana, “... la distancia entre el mundo de la Revolución Francesa y el mundo actual es la que media entre la revolución de la burguesía, alcanzada cabalgando sobre la angustia de las clases populares movilizadas, y la transición al socialismo que - a pesar del descrédito parcial generado por su mala práctica y mal conducción - imprimen su sello a la historia actual...” (64).

La aspiración de superar a la inhumana sociedad burguesa y la entrada a una sociedad más justa, llámese socialista o no, se mantiene y se reafirma en los sectores más consecuentes y auténticos del pensamiento marxista en América Latina, de una forma más diáfana, por las urgencias sociales de esta región, que la que puede apreciarse en las izquierdas de los países desarrollados.

Cuando las circunstancias resultan más adversas, las ideas humanistas que se orientan hacia el socialismo resultan más utópicas y encuentran un menor eco en sectores sociales, precisamente necesitados de las transformaciones revolucionarias. Este hecho no es exclusivo de los defensores de las ideas marxistas o socialistas, sino que se ha repetido en la historia humana cuando revolucionarios, innovadores, descubridores, entre otros, han sido subvalorados por sus coetáneos y sólo pocos son capaces de entrever la magnitud, trascendencia y fortaleza de estos hombres superiores.

Hay hombres que por sí solos hacen todo lo posible por mover una montaña; en tanto, hay otros que intentan en vano atrapar y hasta paralizar una nube. A los primeros, aunque no lo logren, hay que agradecerles sus aportes al progreso de la humanidad; a los segundos, sólo hay que admitir que se convierten en nuevas montañas que a su vez exigirán ser empujadas.

Los que en los últimos años han cultivado en el mundo anglosajón el llamado marxismo analitico, con la perspectiva de reivindicar los fundamentos metodológicos y la cientificidad contenida en múltiples abstracciones efectuadas por Marx en el estudio de la historia real, plantean con razón que "probablemente la mayor tarea del marxismo de hoy sea construir una teoría moderna del socialismo. Tal teoría debe incluir una explicación de las ineficiencias e injusticias del capitalismo moderno, así como un proyecto histórico para corregir esas fallas en una sociedad socialista factible" $(65)$.

En verdad la tarea de los marxistas en la actualidad consiste tanto en revelar las evidentes contradicciones del capitalismo y su carácter inhumano, como en elaborar, proponer y emprender un proyecto socialista más acorde con las exigencias que el hombre moderno ha conquistado y que no está dispuesto a renunciar, a pesar de los augurios postmodernistas. 
Eduardo Galeano ha sostenido que "el capitalismo puede matar al socialismo, pero está condenado a engendrarlo siempre" (66). No es cuestión de discutir si lo ocurrido al llamado socialismo real fue un suicidio o se trató de un asesinato, lo cierto es que vencieron indiscutiblemente, por una u outra razón, las fuerzas del capitalismo y para muchos ilusos de una vez y por todas.

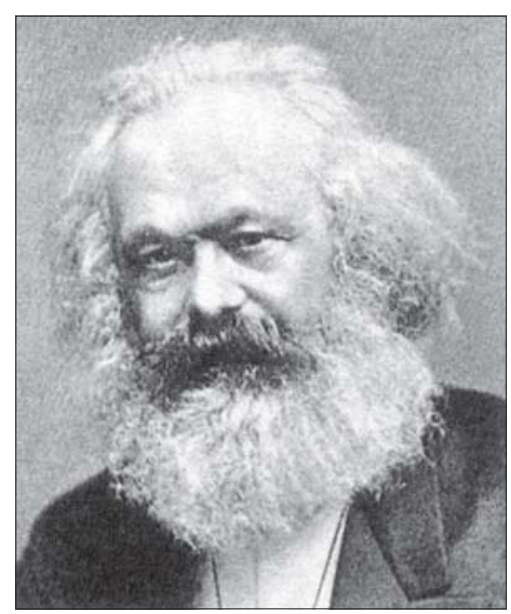

Karl Marx (1818-1883)

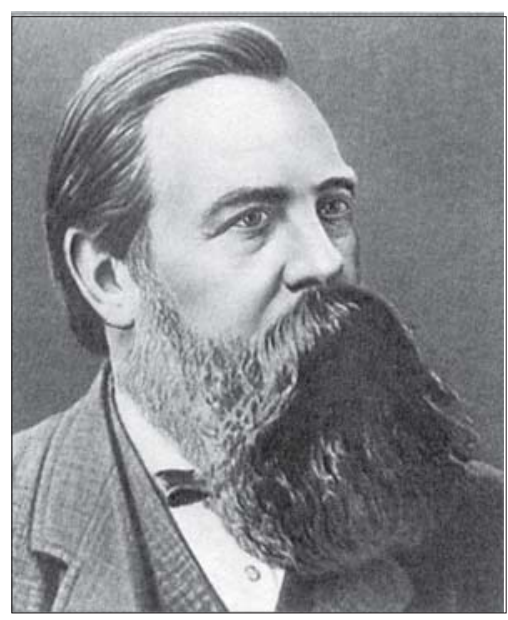

Friedrich Engels (1820-1895)

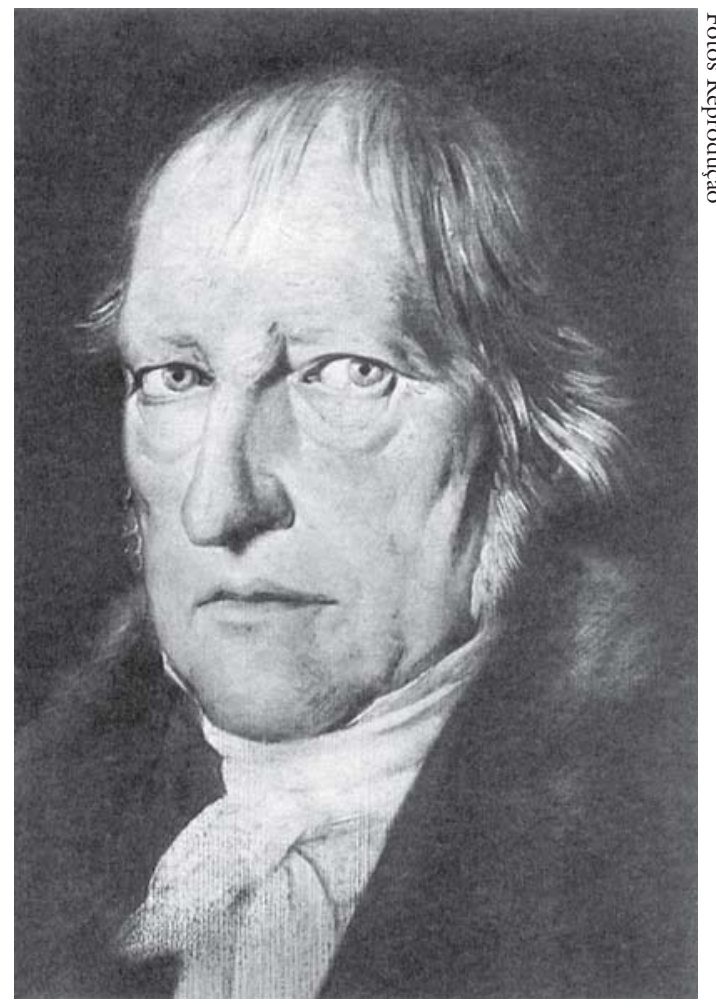

Georg Hegel (1770-1831)

No ha habido que esperar mucho tiempo para observar la fuerza pendulante hacia la izquierda que se ha producido en varios de aquellos países que no hace mucho renunciaron a la construcción del socialismo, dando muestras de que el capitalismo consecuentemente movido por sus mecanismos espontáneos es hostil al humanismo por naturaleza y genera de algún modo los fermentos para su crítica y superación, sean o no considerados propiamente socialistas.

Sin la reivindicación del humanismo en el marxismo y en el proyecto socialista al que tantos hombres, y no sólo Marx, han consagrado su vida y su obra, no 
es posible la reconstrucción de ningún tipo de humanismo. Y entonces a la humanidad no le interesará tanto que sea o no marxista, pero sí le preocupará, en especial, que sea auténtico humanismo práctico, independientemente de cómo se le denomine y de qué región del mundo provengan las mejores experiencias de su ejecución. Los marxistas en América Latina, como en todas partes, tienen ahora ante sí una magnífica oportunidad para continuar su labor reivindicadora del humanismo consustancial a esta teoría. Tal reivindicación no significa en modo alguno una simple reproducción de los mismos parámetros que se planteó Marx en cuanto a la liberación humana en su época, pues sus puntos de referencia eran lógicamente distintos de los que se les plantea, a fines del siglo XX, a los preocupados por emancipar al hombre de las nuevas formas de enajenación que se han ido generando, incluso de aquellas que se engendraron en los propios ensayos socialistas recién fracasados.

Uno de los elementos aún utópicos que observa Sánchez Vázquez en las ideas de Marx es "considerar que en el comunismo no habrá ningún tipo de enajenación, pues si hay formas de objetivación habrá posibilidades de enajenación" (67). Es lógico que mientras exista el capitalismo, independientemente de todas las variantes cosméticas que emplee, existirá la forma más cruda de enajenación en cuanto a la relación del hombre con el trabajo. Pero algo muy interesante se observa con el proceso de incremento de la productividad del trabajo, la tecnificación, robotización etc., que reduce cada vez más la porción de la población que desarolla actividades productivas. Esto da lugar a que prolifere cada vez más la esfera de los servicios, pero también a que se incrementen sustancialmente los momentos de ocio culto en grandes sectores, especialmente en los países desarrollados y, aunque en menor medida, esto también es apreciado en determinados grupos sociales de los países más atrasados.

Ya sea por una causa o por otra, por desempleo inducido forzosamente o por decisión voluntaria, lo cierto es que la enajenación alcanza modalidades insospechadas. En tal sentido el pensamiento marxista contemporáneo tiene nuevos retos, pues debe ser capaz de elaborar concepciones y, lo que es más difícil, tratar de ponerlas en práctica, de modo a que contribuyan a la liberación por parte del hombre contemporáneo de esas nuevas formas de explotación y enajenación, con independencia de que algunos individuos, incluso sectores sociales determinados, prefieran continuar enajenados.

Ante las nuevas circunstancias se espera de los marxistas de esta época un significativo cambio de horizonte y actitudes, pues ante todo se requiere el análisis de la experiencia del ensayo fracasado (68) y la reformulación tanto de consignas como de criterios objetivamente fundados. Esto implica mantener los principios emancipatorios que han caracterizado siempre a los revolucionarios y los objetivos de perfeccionamiento humano. Por eso Tomás Borge sostiene que "El socialismo, en última instancia, es la creación del hombre nuevo, del ciudadano del siglo XXI: un hombre que tenga horror a los lugares comunes y a la arrogancia, que entienda la libertad como algo inherente a la revolución, que sea enemigo del esquema y amante de la herejía, crítico y soñador" (69). 
En el pensamiento marxista latinoamericano ha habido pujantes manifestaciones de autenticidad cuando hombres de distintas generaciones, como Mella, Mariátegui o el Che, han utilizado el instrumental de análisis que ofrece la concepción dialéctico-materialista de la historia para interpretar sus respectivas circunstancias y tratar de transformarlas. Pero la historia de dicho pensamiento revela muchas expresiones también de inautenticidad cuando se importaron esquemas y se trasladaron fórmulas muy inaplicables a la realidad latinoamericana.

El deterioro gradual del proyecto humanista que animaba el ideal socialista de Marx, Engels, Lenin y tantos otros marxistas en distintas partes del mundo, y, finalmente, el impacto causado por el derrumbe del sistema socialista causaron perplejidad profunda en la intelectualidad marxista $-\mathrm{y}$ en general de izquierda en América Latina respecto a las posibilidades reales de construir dicho proyecto. Pero sería absurdo sostener que actualmente la izquierda se encuentra absolutamente desorientada y que ha perdido totalmente la perspectiva de orientación socialista, porque el socialismo no se encuentra ante las puertas inmediatas de la historia como parecía estarlo apenas dos décadas atrás. En verdad se han extraído las experiencias necesarias y sobre todo se aprecia que los llamados modelos de socialismo hasta el presente ensayados requieren una reformulación. Como plantea el inclaudicable marxista mexicano Gabriel Vargas Lozano, “... el problema no es de nombres, sino de construir un nuevo modelo, una nueva síntesis que preserve, por un lado, los ideales humanistas del socialismo, que extraiga los resultados objetivos de la experiencia pasada, que proteja las libertades esenciales del hombre y la mujer y que enfrente los inmensos problemas que resultarán de los nuevos desarrollos de la ciencia y la tecnología. Hoy se requiere fundar de nuevo el socialismo y la democracia en una estrategia a corto, mediano y largo plazos. No se trata de fundar una nueva utopía, sino de encontrar una salida a los desafíos de nuestro tiempo" (70). Y esa salida, a nuestro juicio, ya se demostró que para las mayorías, tanto de América Latina como de otras latitudes, no radica en el capitalismo.

En la actualidad, el pensamiento de la izquierda tiene muchas posibilidades de contribuir desprejuiciadamente a la marcha progresiva de la historia. Entre ellas está reivindicar el humanismo contenido en el marxismo no sólo con brillantes análisis teóricos - los cuales no deben faltar en una época en que parece ponerse a prueba el valor de toda teoría -, sino a través de una praxis política y social cotidiana que permita medir el grado de efectividad en la dignificación de tantos hombres que se encuentran aún en estado subhumano.

La condición de revolucionaria no se le ortogará a dicha praxis y la consecuente fundamentación teórica simplemente por la forma, la táctica o la estrategia, sino por la medición progresiva que de ellas hagan en su tiempo las futuras generaciones conscientes de esa trayectoria humanista, tanto en el pensamiento latinoamericano como en la más genuina tradición socialista y marxista en cualquier país. Al vacunarlas de la voracidad misantrópica de algunas posturas postmodernistas se coadyuva a tal empeño. 
Notas

1 Unzueta, Gerardo. Las dos primaveras de Dubcek. En: Memoria, México, n. 49, p. 29,1992 .

2 "Los principios humanistas del pensamiento de Marx parten de la realidad social concreta a la cual somete la interacción de los individuos la acumulación del capital bajo la tutela de un Estado de clase. Bajo cierto aspecto, están presentes en esos principios los valores de protesta social y de crítica histórica heredados del cristianismo primitivo y de la filosofía de las luces". Marques, J. Luiz. O socialismo. Porto Alegre, Editora da Universidade, Universidade Federal do Rio Grande do Sul, 1991, p. 67.

3 Silva, Ludovico. Humanismo clásico y humanismo marxista. Caracas, Monte Avila Editores, p. 231-244.

4 "El humanismo martiano no está marcado por formulaciones abstractas, como en ocasiones se les exige a los filósofos. Es un humanismo concreto, revolucionario, ante todo, práctico, porque está concebido para transformar al hombre en su circunstancia, al transformar las circunstancias que condicionan al hombre. En su caso el cubano, el latinoamericano que no disponía de auténticas condiciones humanas de existencia". Guadarrama, Pablo. Humanismo práctico y desalienación en José Martí. En: Ottmar Ette y Fitus Heydenreich, José Martí 1895-1995. Literatura. Politica. Filosofía. Estética, Vervuert Verlag, Universität Erlangen-Nürnberg, 1994, p. 34-35.

5 Véase: Colectivo de autores. El derrumbe del modelo eurosoviético: una visión desde Cuba. La Habana, Editorial Félix Varela, 1994; Guadarrama González, Pablo. Marxismo y antimarxismo en América Latina. Bogotá, Universidad INCCA de Colombia, 1990; $2^{\text {a }}$ ed.: México, Editora Política, La Habana-Editorial El Caballito; Antinomias de la crisis del socialismo. La Habana, Editora Política, 1992; América Latina marxismo y postmodernidad.Bogotá, Universidad INCCA de Colombia, 1994. Posmodernismo y crisis del marxismo. México, Universidad Autónoma del Estado de México, 1994.

6 Fornet-Betancourt, Raúl. Ein anderer Marxismus? Die philosophische Rezeption des Marxismus in Lateinamerika. Mainz, Mathias Grünewald Verlag, 1994, p. 11.

7 "Lo que esta aproximación pretende no es, pues, ser una historia del movimiento obrero o de algún partido político, sino una historia del pensamiento marxista español. Se trata, por tanto, de historia de las ideas. Pero para el autor de este trabajo las ideas no flotan en las nubes ni son productos que puedan surgir en cualquier momento de la historia, sino que surgen en un concreto suelo histórico y se insertan en la dinámica histórica". Ribas, Pedro. Aproximación a la historia del marxismo español. (18691939). Madrid, Ediciones Endymion, 1990, p. 9.

8 Sánchez Vázquez, Adolfo. Socialismo y marxismo, hoy. Mesa redonda del IV Congreso de Filosofía de México. Toluca, 24 nov. 1987. Universidad Autónoma del Estado de México, 1987.

9 Guadarrama González, P. Razones de confluencia y divergencia entre el pensamiento latinoamericano y el humanismo socialista. En: Islas, n. 110, 1995.

10 "Tal como la metafísica cristiana no ha impedido a Occidente grandes realizaciones materiales, el materialismo marxista conpendia, como ya he afirmado en otra ocasión, todas las posibilidades de ascención moral, espiritual y filosófica de nuestra época”. 
Mariátegui, J.C. Defensa del marxismo. Obras Completas. Lima, Editora Amauta, 1985, p. 104.

11 Ponce, A. Humanismo burgués y humanismo proletario, En: Obras. La Habana, Casa de Las Américas, 1975, p. 233.

12 Lukacs, G. Historia y conciencia de clase. La Habana, Editorial Cien. Soc.., 1970, p. 136.

13 Kolakowski, Leszek. Las principales corrientes del marxismo. T-III. La crisis. Alianza Universidad, 1983, p. 179.

14 Revueltas, Andrea; Rodrigo Martínez \& Philippe Cheron. Prólogo. Ensayo sobre un proletariado sin cabeza. En: José Revueltas. Obras Completas, t. 17. México, Ediciones Era, 1980, p. 18.

15 Id., ibid., p. 60.

16 "El materialismo histórico, como he dicho, es un humanismo, pero un humanismo realista, que ve la humanidad en la realidad de su historia, la cual es sin duda alguna, obra de los hombres. Pero no obra arbitraria y sin limitaciones, sino condicionada siempre por la realidad existente, en su mismo esfuerzo de superación y transformación. En este sentido, precisamente, el materialismo histórico fue definido por sus creadores como un real humanismo, y como tal debemos reconocerlo". Mondolfo, R. El humanismo de Marx. México, Fondo de Cultura Económica, 1977, p. 28-29.

17 Id., ibid., p. 11-12.

18 Guadarrama González, Pablo. Tendencias en la recepción del marxismo en el pensamiento filosófico cubano. Revista Cubana de Ciencias Sociales, La Habana, n. 16, p. 16-36, ene./abr. 1988; Guadarrama González, P.; Rojas, M. y otros. El pensamiento filosófico en Cuba en el siglo XX. (1900-1960). México, Universidad Autónoma del Estado de México, 1994.

19 Vásquez, Eduardo. Libertad y enajenación. Caracas, Monte Avila Editores, 1987, p. 32-34.

20 Id. Ibid.

21 Seve, L. Marxismo y teoría de la personalidad. Buenos Aires, Amorrortu Editores, 1975, p. 77.

22 Goldman, Lucien. Marxismo y ciencias humanas. Buenos Aires, Amorrortu Editores, 1975 , p. 238.

23 "Ni el logicismo, ni el existencialismo, ni la fenomenología han demostrado en absoluto ser filosofías de transformación. Tampoco lo ha demostrado la 'filosofía marxista' si por ello se entiende ese sistema ideológico de rigidez egipciaca que suele circular". Silva, Ludovico. La alienación en el joven Marx. México, Editorial Nuestro Tiempo, 1979, p. 68.

24 Caletti, Oberdán. Prólogo a El humanismo de Marx, de Rodolfo Mondolfo. Fondo de Cultura Económica, 1973, p. 8.

25 Aricó, José. Marxy América Latina. México, Alianza Editorial Mexicana, 1982, p. 47.

26 "Me lo aplico a mí mismo, con las debidas restricciones, respecto al tema pasado, presente y porvenir del marxismo, y más aún en su forma de pasado, presente y porvenir del humanismo positivo. Mas estoy convencido, con Marx, que solamente llegará a 
ser real y efectivamente universal, cuando deje de ser mío, y pase a serlo de sociedad; lo sea de todos vosotros a la una. Y deseo que la sociedad, todos nosotros a la una, cambien no sólo la forma sino el contenido del tema". Presente, pasado y porvenir de Marx y del marxismo. México, Fondo de Cultura Económica, 1985, p. 68.

27 García, Antonio. Dialéctica de la democracia. Bogotá, Plaza y Janes, 1987, p. 101.

28 "Quizás están en lo cierto los pensadores que hablan ahora de la conveniencia de un socialismo humano en que el individuo mide severamente lo que en realidad requiere para ser feliz, sin los sueños demesurados del siglo XIX". Molina, Gerardo. Las ideas socialistas en Colombia. Bogotá, Tercer Mundo Editores, 1988, p. 348.

29 Zuleta, Estanislao. Sobre la idealización en la vida personal y colectiva y otros ensayos. Bogotá, Procultura, 1985. p. 53.

30 “¿El marxismo podrá construir una nueva antropología y liquidar sus ilusiones? ¿O no podrá? Yo creo que podría hacerlo, liquidando su ilusión de que vamos encaminados por no sé qué mecanismo histórico hacia una fiesta final. Liquidar también la idea de que la sociedad pueda ser armónica, no conflictiva, sin leyes, sin gobierno, sin nada, porque ya no habrá propiedad privada". Zuleta, Estanislao. Ensayos sobre Marx. Medellin, Ediciones Percepción, 1987, p. 31.

31 Jaramillo, Rubén. Recepción e incidencias del marxismo. En: Tendencias actuales de la filosofía en Colombia. Bogotá, USTA, 1988, p. 233.

32 Fals Borda, Orlando. Marx y el Tercer Mundo. El marxismo en Colombia. Bogotá, Universidad Nacional de Colombia, 1983, p. 23.

33 “... no un Marx profeta, sino un Marx guía. Un Marx para guiarnos en la construcción del socialismo; de un socialismo libre de aquellos lastres, que se perfila como antidogmático y que se ajusta mucho mejor, por lo mismo a las realidades de cada cultura, de cada región, de cada época. Si se cumple esto se puede decir que el pensamiento de Marx seguirá vivo por mucho tiempo más y que en nuestros países estaremos recogiendo sus enseñanzas prístinas, esperanzados en que a nosotros nos den quizás superiores resultados que aquellos que hasta el momento hemos observado en otros países, aún donde se han realizado revoluciones socialistas exitosas". Marx y el Tercer Mundo. El marxismo en Colombia. Bogotá, Universidad Nacional de Colombia, 1983, p. 13.

34 Vaz Ferreira. Sobre los problemas sociales. Buenos Aires, Editorial Losada, 1939, p. 45.

35 Palacios, Alfredo. Una revolución auténtica. Buenos Aires, Ediciones Teoría y Práctica, 1985, p. 96.

36 Ribeiro, Darcy. América y la civilización. La Habana, Casa de Las Américas, 1992, p. 53.

37 Bendaña, Alejandro. El sandinismo ante el colapso del comunismo. En: La Avispa. Managua, dic. 1990/ene. 1991, p. 6.

38 "Hoy está de moda pintar de blanco y negro la situación de los países de Europa del Este. Y así como no faltó quienes los describieran hasta no hace mucho como verdaderos paraísos, o al menos como sitios en que se había establecido el socialismo real o el único socialismo posible, ahora se habla de ellos como engendros antidemocráticos en que todo fracasó. Y eso es paladinamente falso. Esos países y la humanidad en general deben mucho a esas experiencias socialistas". Ayala Mora, 
Enrique. La crisis del socialismo. Desafíos y perspectivas en el Ecuador y América Latina, p. 14.

39 “... hubo un agotamiento del modelo de economía centralmente planificada. Agotamiento en dos sentidos: 1) en relación con su quehacer histórico anterior, porque el socialismo allí en Europa Oriental solucionó importantes problemas sociales. El agotamiento se debe a la necesidad de mayor eficiencia económica y de ampliación de la democracia; 2) en comparación con los ritmos de crecimiento, productividad, desarrollo tecnológico etc., con los países capitalistas desarrollados...”. Ortega, Eloy. La crisis del socialismo en Europa Oriental y su impacto en el Tercer Mundo”. En: Revista de Estudios Europeos, p. 20, ene./mayo 1991.

40 Alvarez, Federico; Calello, Hugo; Kohn, Carlos y otros. Democracia y violencia politica. Caracas, Universidad Central de Venezuela, 1990.

41 Una posición muy atinada es la que sugiere este marxista peruano cuando sostiene: "Hay una vasta literatura de debate en la izquierda socialista, que no admitió desde el comienzo, y que ahora crecientemente la mayor parte no admite de que sea, se trate simplemente de socialismo. La cuestión está por lo tanto abierta. Es demasiado compleja para que tenga una respuesta del tipo yo creo, tú crees; los estudios están comenzando y hay que ponerse a estudiar". Quijano, Aníbal. Después de la caída: el significado de la crisis del socialismo para América Latina y Europa del Este. Heraclio Bonilla (ed.). Ecuador, FLACSO, 1992.

42 “'Realmente había socialismo en la Unión Soviética y los demás miembros del difunto Pacto de Varsovia? Sostener esto es reducir ese ideal a la estatización, base de un igualistarismo voluntarista muy pobre en contenido humano, sistema impuesto precisamente allí a lo largo de varias décadas". Becerra, Longino. El marxismo y realidad nacional. Tegucigalpa, Editorial Baktun, 1991, p. 13.

43 "Dichas sociedades - decíamos por entonces - [este planteamiento fue originalmente hecho por Sánchez Vásquez desde finales de los 70 (P.G.)] no son socialistas ni siquiera en sentido restringido, ya que en ellas la propiedad estatal no es sólo la antítesis de la propiedad social. Por otro lado, agregábamos, su superestructura antidemocrática, lejos de estar en oposición a la base económica de propiedad estatal, es justamente la que le corresponde, ya que como ella escapa al control social". Sánchez Vásquez. “¿De qué socialismo hablamos? Puebla, Dialéctica, año 15, n. 21, p. 25, Invierno 1991.

44 En los últimos años son cada vez más abundantes en América Latina los eventos y las publicaciones colectivas, además de las individuales, dedicadas al análisis del las causas y efectos del derrumbe del socialismo y la crisis del marxismo. Véase entre otros: Socialismo, realidad y vigencia. Universidad Nacional de Colombia, 1991; Coloquio de invierno, Vuelta, 1992; El marxismo contemporáneo, Itztapalapa, Puebla, UNAM; El colapso del socialismo real. En: Puebla, Dialéctica, n. 21, Invierno 1991; Después de la caída, Ecuador, FLACSO, 1992; Después de la caida. El fracaso del comunismo y el futuro del socialismo. Robert Blackburn (ed.). México, Cambio XXI, 1994.

45 “... el socialismo es imposible sin un régimen democrático que efectivamente socialice la propiedad, la dirección de la economía y los asuntos del Estado". Montes, Eduardo. Ser de izquierda hoy. Puebla, Dialéctica n. 23-24, p. 80, Invierno 1992/Primavera 1993.

46 "Sólo una conciencia, pues, socialista, crítica y creadora, bien informada, basada en ese humanismo real (el problema del hombre) y en esa concepción científica de la 
historia (el problema de la historia); las dos fundadas en la verdad (verdad filosóficaverdad científica), pueden forjar una concepción humanista y democrática del socialismo". Núñez Tenorio, J.R. De Marx a la perestroika. Caracas, Fondo Editorial Tropykos, 1991, p. 151.

47 Semo, Enrique. El colapso del socialismo. Managua, La Avispa, n. 2, p. 37, 1990.

48 Dirección política de las Fuerzas Armadas revolucionarias. El derrumbe del socialismo en Europa del Este. Causas y consecuencias. La Habana, 1992, p. 13.

49 Dussel, E. Retos actuales a la filosofía de la liberación en América Latina. Porto Alegre, Liberação, n. 1, p. 26, 1989.

50 Guadarrama González, P. y colectivo de autores. Humanismo y filosofía de la liberación latinoamericana. Bogotá, Editora El Buho, 1993; Islas, Santa Clara, Revista de la Universidad Central de Las Villas, n. 99, 1991.

51 Cerutti Guldberg, H. La recepción del marxismo por el pensamiento cristiano latinoamericano. Puebla, Dialéctica, n. 19, p. 81, jul. 1988.

52 Guadarrama González, P. La dimensión concreta de lo humano en Mariátegui. En: México, Coatepec, Revista de la Facultad de Humanidades de la Universidad Autónoma del Estado de México, 1995.

53 Díaz Polanco, Héctor. El quinto centenario de los pueblos indios. En: Casa de Las Américas, n. 189, p. 55, jul./sept. 1992.

54 Saladino G., A.. Indigenismo y marxismo en América Latina. Toluca, UAEM, 1994, p. 261.

55 González Casanova, Pablo. Colonialismo interno, una definición. América Latina. Historia y destino. Homenaje a Leopoldo Zea. México, UNAM, 1992, p. 266.

56 Id. Sobre el marxismo en América Latina. Puebla, Dialéctica, n. 20, p. 16, dic. 1988.

57 Moulian, Tomas. Los sueños perdidos de la izquierda. En: México, La Jornada Semanal, 30 mar. 1986.

58 Cerdas, Rodolfo. Un marxismo sin marxismo. La crisis de una escolástica. En: Sobrevivirá el marxismo. San José, Editorial de la Universidad de Costa Rica, 1991.

59 Brown Infante, Francisco. Europa Oriental: economía de mercado, el factor hombre y la utopía socialdemócrata. Revista de Estudios Europeos, Centro de Estudios Europeos, p. 11, ene./mar. 1991.

60 "Hasta hace poco, la preocupación acerca de esta problemática del morir y la muerte, se la cedíamos en gran medida, a la filosofía burguesa y la teología”. Koyné, Klaus. Problemas del humanismo en la sociedad socialista. Hojas universitarias. Bogotá, Universidad Central, v. II, n. 20, sept. 1984.

61 Guadarrama González, P. La reivindicación del humanismo en el marxismo latinoamericano. Bogotá, Universidad INCCA de Colombia, n. 7, p. 27-29, ago. 1994.

62 Castañeda, Jorge. La utopía desarmada. Bogotá. Tercer Mundo Editores, 1994, p. 26.

63 Bonilla, Heraclés (ed.), obra citada, p. 29.

64 Campana, Arturo. Editorial. Quito, Espacios, n. 3, p. 4, ene. 1994.

65 Roemer, John E. El marxismo: una perspectiva analitica. Fondo de Cultura Económica, 1989 , p. 10. 
66 Galeano, Eduardo. La realidad es un desafío. La Habana, Bobemia, I ene. 1993.

67 Sánchez Vásquez, A. Del socialismo científico al socialismo utópico. México, Ediciones Era, 1981, p. 54.

68 "Ser marxista al final del siglo XX - plantea Francisco Fernández Buey - quiere decir ayudar a la formación de una nueva teoría de la emancipación humana, contribuir a la renovación de una tradición liberadora que viene de lejos, pero que necesita ahora, después de la derrota, asimilar hechos tan nuevos como que vivimos en un 'Imperio único' (con el aumento en flecha del número de siervos), bajo la amenaza de una crisis ecológica que sólo podrá impedirse mediante cambios drásticos en el modo de vida típico de las sociedades capitalistas y con diferencias sociales más agudas que las que conoció Marx". Fernández Buey, Francisco. "¿Qué quiere decir ser marxista al final del siglo XX? México, Memoria, n. 49, p. 47, dic. 1992.

69 Borges, T. Presentación. Un grano de maiz. Fidel Castro. Conversación con Tomás Borge. La Habana, Oficina de Publicaciones del Consejo de Estado, 1992, p. 11.

70 Vargas Lozano, Gabriel. Más allá del derrumbe. México, Siglo XXI Editores, 1994, p. 102.

Pablo Guadarrama González é professor da Universidad Central de Las Villas, Santa Clara, Cuba.

Palestra feita pelo autor no encerramento do Coloquio Internacional de Publicaciones de Reflexión de América Latina y el Caribe, realizado de 12 a 15 de dezembro de $1995 \mathrm{em}$ Santiago de Cuba.

Revisão de Neide González. 